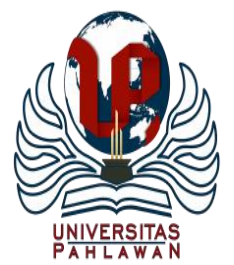

Edukatif : Jurnal Ilmu Pendidikan Volume 3 Nomor 2 Tahun 2021 Halm 364 - 375

EDUKATIF: JURNAL ILMU PENDIDIKAN

Research \& Learning in Education

https://edukatif.org/index.php/edukatif/index

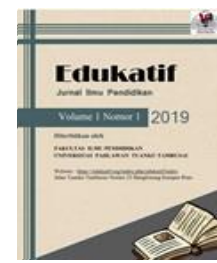

\title{
Media Pembelajaran Interakif Menggunakan Adobe Flash CS6 Untuk Pembelajaran IPS Siswa Sekolah Menengah Atas
}

\author{
Vivin Muthoharoh $^{1 凶}$, Norida Canda Sakti ${ }^{2}$ \\ Universitas Negeri Surabaya ${ }^{1,2}$ \\ E-mail : vivin.17080554071@ mhs.unesa.ac.id ${ }^{1},{\underline{\text { noridacanda@ } \text { unesa.ac.id }^{2}}}^{2}$
}

\begin{abstract}
Abstrak
Penelitian ini dilatarbelakangi banyaknya peserta didik menjadi murid yang pasif serta kurang termotivasi terhadap metode pembelajaran konveksional yang biasa digunakan oleh guru, yang mana pembelajaran dilakukan menyampaikan materi secara lisan lalu mengerjakan soal evaluasi. Dari paparan permasalahan tersebut penelitian dilakukan untuk mengembangkan media pembelajaran interaktif yang mampu memacu peserta didik agar lebih bersemangat dan meningkatkan hasil belajar peserta didik. Penelitian pengembanagn ini menggunakan jenis penelitian yakni Research and Development (R\&D) serta model penelitian 4D (Define, Design, Development dan Disseminate). Uji coba terbatas sebanyak 20 peserta didik. Penelitian dilakukan guna meninjau kelayakan media jika diketahui dari penyajian media dan kesesuaian materi, efektivitas media, kepraktisan media serta guna menganalisis respon peserta didik dan perbandingan hasil belajar ketika sebelum dan setelah mengakses media dengan desain uji coba Pre-Test dan Post-Test. Sedangkan hasil belajar dianalisa melalui uji $\mathrm{N}$-Gain Score. Berdasarkan hasil uji coba terbatas diperoleh yakni media pembelajaran diketahui layak karena mendapatkan hasil sebesar $85,7 \%$, efektif sebab diperoleh skor $100 \%$, dan praktis dengan presentase $100 \%$ apabila digunakan. Selain itu diketahui peserta didik merespon positif dengan menunjukkan bahwa media pembelajaran perpajakan memberikan rasa antusias jika digunakan. Hasil belajar juga meningkat secara signifikan setelah mengakses media pembelajaran perpajakan.
\end{abstract}

Kata Kunci: media pembelajaran, adobe flash cs6, ekonomi, respon.

\section{Abstract}

This research is based on the number of students which is passive students and less motivated to method of convectional learning commonly used by teachers, where learning is done verbally and then work on evaluation questions. The type of research is Research and Development $(R \& D)$ with $4 D$ research model (Define, Design, Development and Disseminate). Limited trial of 20 students. Research was conducted to determine the feasibility of the media if reviewed from the presentation of media and the suitability of the material, the effectiveness of the media, the practicality of the media and to analyze the response of learners and comparison of learning outcomes before and after using the media with the design of pre-test and posttest trials. The learning results were analyzed using the $\mathrm{N}$-Gain Score test. From the results of limited trials obtained that learning media is known to be feasible with score $85,7 \%$, effective with score $100 \%$ and practical with score $100 \%$ when used. In addition, the students gave a positive response that showed that the learning media provides a sense of enthusiasm if used. Learning media is also proven to significantly improve students' score.

Keywords: learning media, adobe flash cs6, economic, students responses.

Copyright (c) 2021 Vivin Muthoharoh, Norida Canda Sakti

$\triangle$ Corresponding author

Email : vivin.17080554071@mhs.unesa.ac.id

DOI $\quad$ : https://doi.org/10.31004/edukatif.v3i2.315

ISSN 2656-8063 (Media Cetak)

ISSN 2656-8071 (Media Online)

Edukatif : Jurnal Ilmu Pendidikan Vol 3 No 2 Tahun 2021 p-ISSN 2656-8063 e-ISSN 2656-8071 
DOI : https://doi.org/10.31004/edukatif.v3i2.315

\section{PENDAHULUAN}

Pendidikan merupakan perihal penting yang pada dasarnya harus mendapat prioritas utama dalam perhatian publik. Sebab di dalam hal tersebut terdapat proses yang bisa memperbaharui dan mengembangkan kualitas SDM atau sumber daya manusia. Tak bisa dihindari bahwa hasil dari peningkatan kualitas sumber daya manusia tak lain ialah karena adanya pendidikan sebagai mediator pada saat penyampaian kebudayaan dari tahun ke tahun.

Penetapan strategi yang berhubungan dengan tujuan yang diinginkan ialah suatu keharusan. Sebuah upaya untuk menghasilkan pendidikan yang baik yang tersusun sesuai rencana, maka harus memiliki strategi dalam kegiatan pembelajaran. Salah satu cara agara peserta didik bisa berfikir kritis, kreatif, dan rasional rasional terhadap berbagai macam situasi yang terjadi dan yang mungkin terjadi yakni dengan penggunaan strategi pembelajaran yang sesuai target (Asrori, 2016). Penggunaan strategi pembelajaran yang sesuai target dinilai mampu menambah minat serta hasil belajar di kelas.

Pada perkembangan zaman pada segi Ilmu Pengetahuan dan Teknologi dinilai sangat bermanfaat bagi guru untuk lebih menjadi pendidik yang inovatif dan kreatif dalam membuat media pembelajaran bagi peserta didiknya. Meskipun seringkali berkembangnya teknologi, namun juga menimbulkan beberapa dampak sosial serta transformasi di lingkup sosial, akan tetapi bukan berarti sebagai guru mengelak serta enggan mengikuti berkembangnya era (Tafonao, 2018). Adanya teknologi juga mampu menjadikan ruang lingkup belajar peserta didik dan guru menjadi tidak terbatas, sebab dengan teknologi kegiatan belajar mengajar dapat dikerjakan pada saat luar kelas yang mana tentu saja dengan bimbingan guru dan bertujuan menjadikan peserta didik menjadi lebih mandiri dalam memcahkan masalah.

Media pembelajaran merupakan sebuah sarana dalam mendukung penyampaian suatu informasi dalam proses pembelajaran. Media pembelajaran dinilai sungguh-sungguh berguna bagi guru di kelas. Media pembelajaran didesain dengan inovatif dan atraktif maka akan menambah kualitas dan hasil belajar pembelajar di kelas (Muhson, 2010). Media sangat memberikan peran penting untuk membangkitkan rasa semangat pada diri peserta didik pada saat mengikuti pelajaran. Menurut Kurniawati dan Nita (2018) Penggunaan media pembelajaran selain sebagai media yakni sebagai pembuat proses interaksi, komunikasi serta penyampaian sebuah materi antara pendidik dan pembelajar supaya kegiatan pembelajaran berlangsung secara tepat dan efisien. Media pembelajaran yang interaktif terbukti berhasil dan dapat digunakan untuk belajar pada berbagai macam level dari pendidikan serta memberikan banyak dampak positif terutama di Indonesia di mana media interaktif dapat membuat proses belajar peserta didik menjadi lebih mudah (Osman, 2015).

Menurut hasil wawancara bersama peserta didik kelas XI IPS SMAN 1 Krian didapatkan sebanyak 70\% peserta didik menjadi murid yang pasif serta kurang termotivasi terhadap metode pembelajaran konveksional yang biasa digunakan oleh guru, yang mana pembelajaran dilakukan menyampaikan materi secara lisan lalu mengerjakan soal evaluasi. Motivasi diperlukan dalam proses mengembangkan semangat peserta didik pada saat kegiatan belajar di sekolah (Syupriyanti, 2019). Diketahui nilai peserta didik pada mata pelajarn ekonomi khususnya pada KD 3.7 Perpajakan beberapa belum memenuhi KKM (Kriteria Ketuntasan Minimal). Guru menentukan KKM sebanyak 75, namun masih banyak siswa yang nilai ujiannya kurang dari standar. Selain itu di sekolah seringkali guru dalam mengajar menggunakan media yakni media power point, yang mana desain dinilai sedikit inovatif dan cenderung belum memacu semangat belajar peserta didik di kelas. Oleh sebab itu media pembelajaran interaktif hadir untuk membantu proses pembelajaran pendidik dan pembelajar pada beragam mata pelajaran yakni contohnya ekonomi.

Materi pelajarn ekonomi merupakan sebuah ilmu yang mempelajari tentang individu dalam suatu kalangan masyarakat dalam mengurus sumber daya yang ada yang jumlahnya tidak banyak (Mankiw, 2013). 
Seperti yang kita tahu, kepentingan setiap individu memang tidak terbatas, namun sumber daya yang ada jumlahnya bisa dikatakan tidak banyak dalam memenuhi kebutuhan manusia tersebut, oleh karena hal ini Mankiw mendeskripsikan ilmu ekonomi seperti pada uraian di atas.

Dalam mata pelajaran ekonomi terdapat salah satu cabang ilmu yakni parpajakan. Perpajakan merupakan salah satu cabang ilmu ekonomi yang merupakan ilmu terapan di mana tujuannya ialah menjadikan peserta didik menjadi wajib pajak yang taat di kemudian hari. Materi perpajakan diajarkan pada peserta didik jenjang pendidikan SMA tepatnya pada kelas XI. Materi perpajakan diajarkan pada semester genap atau semester dua. Terdapat beberapa alasan mengapa peneliti menggunakan materi perpajakan sebagai materi yang digunakan untuk pengembangan media pembelajaran. Salah satunya yakni materi perpajakan apabila diilustrasikan menggunakan media pembelajaran interaktif maka akan lebih mudah dipahami dan menarik motivasi belajar dari peserta didik sebab di dalam media tersebut terdapat animasi-animasi interaktif.

Animasi-animasi bergerak yang termuat di media yang dikembangkan oleh peneliti cocok sekali digunakan bagi peserta didik dengan tipe belajar audiovisual. Dengan visual atau gambar-gambar yang menarik serta audio atau musik-musik yang menenangkan konsentrasi peserta didik. Di dalam media pembelajaran tersebut juga dilengkapi materi yang sesuai dengan indikator pada Kurikulum 2013 yang mencakup definisi pajak, fungsi, manfaat dan tarif pajak, cara membedakan pajak dengan pungutan resmi lainnya, asas pemungutan pajak dan jenis-jenis pajak. Selain itu dilengkapi dengan kuis di akhir sesi yang bertujuan untuk menguji kemampuan pemahaman siswa pada media pembelajaran yang sudah dipelajari.

Semakin berkembangnya zaman di Indonesia berbagai macam jenis media pembelajaran juga semakin berinovasi dan menarik. Menurut Priandana dan Asto (2015) berpendapat bahwa kebanyakan software presentasi pada saat ini hanya mampu menampilkan materi pelajaran dengan desain yang biasa atau standar. Sebagai upaya untuk mengatasi hal tersebut yakni educational animation, di mana arti secara sempitnya adalah bentuk materi pelajaran berupa sebuah presentasi animasi bergerak dan bergambar sebagai media dalam kegiatan pembelajaran di sekolah. Salah satu contohnya yakni Software Adobe Flash CS6 yakni sebagai media pembelajaran jenis baru di bidang teknologi yang merupakan media pembelajaran jenis audiovisual karena dapat membuat suatu bentuk animasi yang dapat bergerak, menampilkan video, yang juga terdapat suara di dalamnya.

Terdapat beberapa alasan pada saat memilih software adobe flash sebagai media pembelajaran, ialah karena Software Adobe Flash CS6 mempunyai kelebihan yaitu hasil akhir yang dihasilkan berukuran lebih kecil daripada file pada umumnya, lalu pada software ini mampu untuk mengimpor semua gambar dan audio sehingga ketika akan memulai sebuah presentasi dengan software ini menjadi lebih terkesan nyata serta mudah untuk membuat aplikasi (Sugiyono, 2016). Sebagaimana pada penelitian sebelumnya oleh Mustarin (2019) yang berpendapat bahwa kegiatan pembelajaran menjadi lebih hidup dengan diterapkannya media belajar interaktif dengan Adobe Flash CS6 di kelas.

Penelitian sebelumnya dilakukan oleh Sefriani dan Sepriana (2020) dengan memanfaatkan teknologi dalam bentuk smartphone yang biasa digunakan oleh banyak orang, di mana smartphone dapat digunakan semaksimal mungkin ketika belajar. Oleh karenanya, siswa dengan mudah belajar dengan memanfaatkan gadgett yang mereka punya. Menurut Bustomi (2010) yang mana pada penelitian tersebut memanfaatkan software Adobe Flash CS6 sebagai media untuk belajar siswa. Namun hasil yang didapatkan bahwa desain dari media tersebut dinilai kurang menarik dan terkesan standar untuk menarik motivasi belajar peserta didik. Sedangkan menurut Fauziah (2016) yang mana menggunakan software Adobe Flash CS6 sebagai pembuatan media e-modul dinilai layak digunakan tetapi terdapat kekurangan yakni animasi-animasi yang digunakan dinilai kurang dan tidak menggunakan animasi interaktif seperti yang terdapat dalam penelitian pengembangan oleh peneliti. 
Selain untuk memotivasi dan menarik minat belajar peserta didik juga memberi dampak positif untuk guru yakni para guru dapat menyampaikan materi tanpa terbatas konseptual. Berdasarkan latar belakang tersebut, penulis ingin mengembangakan sebuah media pembelajaran jenis visual pada bidang teknologi yang mana diharapkan mampu menaikkan hasil dan ketertarikan belajar peserta didik, serta mengiringi dan memanfaatkan perkembangan zaman di bidang teknologi.

\section{METODE PENELITIAN}

Pada penelitian pengembangan Media Pembelajaran Interaktif menggunakan Adobe Flash CS6 merupakan jenis penelitian Research and Development atau RnD. Sedangkan untuk model penelitian pengembangan ialah model 4D diadaptasi oleh Thiagarajan (1974) yang mana 4D memiliki 4 prosedur pengembangan yakni Define, Design, Development dan Disseminate. Namun pada penelitian pengembangan ini hanya dibatasi hingga proses pengembangan (Development). Disebabkan oleh adanya keterbatasan waktu dan biaya.

Data penelitian didapatkan dari hasil uji coba terbatas kepada reponden dan validator ahli meliputi data kuantitatif dan data kualitatif. Desain uji coba menggunakan digunakan pada penelitian ini yakni menggunakan One Group Pre-test Post-test Design. Desain Pre-Test dan Post-Test merupakan desain uji coba yang sebelum peneliti melakukan uji coba produk peneliti memberikan Pre-test kepada peserta didik. Kemudian setelah media pembelajaran diujicobakan peneliti memberikan Post-test kepada subyek penelitian guna mengamati perbedaan hasil kognitif dari peserta didik pada saat sebelum dan sesudah dilakukan uji coba penggunaan media.

Populasi yang ditentukan yakni 108 peserta didik pada kelas XI IPS SMAN 1 Krian, Sidoarjo. Dan sampel yang digunakan pada penelitian pengembangan media yakni menggunakan Teknik Sampling Purposive. Menurut Sugiyono (2013) teknik Sampling Purposive merupakan teknik menentukan sampel yang digunakan dengan mempertimbangkan beberapa hal tertentu. Hal tersebut yakni responden penelitian harus merupakan peserta didik pengguna smartphone android. Peneliti mempertimbangkan sampel penelitian akan diujicobakan kepada sebanyak maksimal 20 peserta didik dari total populasi. Sebab supaya menghasilkan hasil yang akurat maka sampel yang diambil hanya perlu maksimal 20 peserta didik saja.

Instrumen penelitian pada penelitian ini yaitu melalui angket, wawancara, dokumentasi dan observasi. Lembar angket meliputi : (1) lembar angket validasi oleh ahli media; (2) lembar angket validasi oleh ahli materi; (3) lembar validasi ahli evaluasi; (4) lembar angket validasi kepraktisan media; (5) lembar angket efektivitas media; dan (5) lembar angket respon peserta didik.

Teknik analisis data pada penelitian ini menggunakan teknik analisis data deskriptif kualitatif dan deskriptif kuantitatif. Pada teknik analisis data kualitatif tahap yang dilakukan yakni mengumpulkan data, mereduksi data, dan menyajikan data. Sedangkan pada teknik analisis data kuantitatif prosedur yang dilakukan yakni menganalisis data angket oleh validator ahli dengan skala likert, data angket dari respon peserta didik dengan skala guttman untuk mengetahui tingkat kelayakan, kepraktisan, dan efektivitas media terhadap peserta didik yang dijelaskan pada tabel berikut :

Tabel 1 Kriteria Kelayakan Media Pembelajaran

\begin{tabular}{|l|l|l|l|}
\hline No. & Tingkat Pencapaian & \multicolumn{1}{|c|}{ Kualifikasi } & \multicolumn{1}{c|}{ Keterangan } \\
\hline 1. & $81-100 \%$ & Sangat baik & Sangat layak dan tidak perlu direvisi kembali \\
\hline 2. & $61-80 \%$ & Baik & Layak dan tidak perlu direvisi \\
\hline 3. & $41-80 \%$ & Cukup baik & Kurang layak dan perlu direvisi \\
\hline
\end{tabular}


DOI : https://doi.org/10.31004/edukatif.v3i2.315

\begin{tabular}{|l|l|l|l|}
\hline No. & Tingkat Pencapaian & \multicolumn{1}{c|}{ Kualifikasi } & \multicolumn{1}{c|}{ Keterangan } \\
\hline 4. & $21-40 \%$ & Kurang baik & Tidak layak dan perlu direvisi \\
\hline 5. & $0-20 \%$ & Sangat kurang baik & Sangat tidak layak dan perlu direvisi kembali \\
\hline \multicolumn{2}{r}{ Sumber : (Sugiyono, 2016) }
\end{tabular}

Terdapat soal evaluasi yang disajikan pada Pre-Test dan Post-Test yang sudah divalidasi evaluasi sebelum dilakukan percobaan ke peserta didik yang mana hasilnya dipakai guna mengetahui perbedaan hasil belajar. Hasil data uji coba terbatas dianalisa menggunakan Uji $N$-Gain Score dengan kriteria jika hasil akhir $\geq$ 0,3 maka media pembelajaran interaktif dapat dikatakan sebagai media yang layak digunakan dalam menambah hasil belajar peserta didik.

\section{HASIL DAN PEMBAHASAN}

Penelitian pengembangan bertujuan guna mengetahui tingkat kelayakan ditinjau dari kesesuaian materi dan penyajian media, kepraktisan dan efektivitas media jika diujicobakan kepada peserta didik, serta menganalisis perbandingan hasil belajar sebelum dan sesudah menggunakan media pembelajaran. Berikut prosedur pengembangan media pembelajaran menggunakan model 4D.

\section{Tahap Pendefinisian}

Dalam tahap ini terdapat proses analisis awal, analisis peserta didik, analisis tugas, analisis konsep dan spesifikasi tujuan. Pada analisis awal peneliti menganalisis permasalahan berdasarkan hasil yang didapatkan bahwa diketahui materi perpajakan yang disajikan susah dipahami oleh peserta didik. Sebanyak 70\% peserta didik menjadi murid yang pasif serta kurang termotivasi terhadap metode pembelajaran konveksional yang biasa digunakan oleh guru, yang mana pembelajaran dilakukan menyampaikan materi secara lisan lalu mengerjakan soal evaluasi. Selain itu di sekolah seringkali guru dalam mengajar menggunakan media yakni media power point, yang mana desain dinilai sedikit inovatif dan cenderung belum memacu semangat belajar peserta didik di kelas.

Pada analisis peserta didik dilakukan dengan observasi observasi awal di SMAN 1 Krian Sidoarjo untuk melihat respon dan perbandingan hasil belajar dari peserta didik terhadap media yang disajikan. Didapatkan bahwa rata-rata peserta didik menggunakan smartphone android.

Analisis tugas bertujuan agar peserta didik memahami tugas pada pembelajaran yang disajikan. Tugas yang dikerjakan oleh peserta didik adalah mengerjakan Pre-Test dan Post-Test yang sudah disajikan pada media pembelajaran perpajakan dalam bentuk soal benar-salah dengan ranah kognitif C2 atau tingkat pemahaman.

Pada analisis konsep peneliti menganalisa konsep-konsep dasar yang nantinya digunakan pada media, menyusun materi secara prosedural dan merinci konsep-konsep pada materi. Materi yang digunakan adalah pada Kompetensi Dasar 3.7 Menganalisis Perpajakan Dalam Pembangunan Ekonomi. Pada media pembelajaran, peneliti menambahkan menu peta konsep yang berisi indikator dan bagan peta konsep dari materi yang ditentukan. Tahap spesifikasi tujuan dilakukan dengan mengidentifikasi kurikulum yang berlaku. Lalu menentukan tujuan pembelajaran yang sesuai. 
DOI : https://doi.org/10.31004/edukatif.v3i2.315

\section{Tahap Perancangan}

Tahap awal dari tahap perancangan adalah menyusun storyboard dengan membuat kerangka awal media pembelajaran. Storyboard pada media ini berisi menu intro awal, lalu menu utama, sub menu materi, sub menu kuis dan terakhir profil. Pada bagian intro media Tampilan berupa intro atau opening dengan logo perpajakan diiringi dengan efek audio khusus. Menu intro awal memiliki fungsi yakni sebagai pengantar ke scene selanjutnya yaitu scene menu utama.

Bagian menu utama terdapat tombol close denagn fungsi untuk keluar dari aplikasi, jam digital supaya pengguna bisa tahu pukul berapa pada saat menggunakan aplikasi, judul "Media Pembelajaran Interaktif Perpajakan" sebagai icon dari aplikasi, Kompetensi Dasar 3.7 Menganalisis Perpajakan Dalam Pembangunan Ekonomi. Serta terdapat 4 sub menu yang berisi peta konsep, materi, kuis, dan profil.

Pada bagian Sub Menu Peta Konsep berisi peta konsep dengan dirancang menggunakan warna-warna yang menarik mata dan indikator dari Kompetensi Dasar 3.7. Pada bagian materi terdiri dari materi singkat yang sesuai dengan indikator yang sudah terdapat pada menu peta konsep. Dirancang dengan desain yang menarik dan animasi bergerak supaya meningkatkan semangat belajar peserta didik dalam membaca materi yang disajikan.

Setelah membaca dan memahami materi perpajakan pada menu materi, peserta didik dapat menguji hasil pemahaman dengan mengerjakan 10 soal kuis evaluasi pada sub menu kuis. Pada bagian Sub Menu Kuis terdapat halaman awal yang berisi input identitas diri peserta didik. Lalu untuk memulai kuis dapat menekan tombol "MULAI". Disediakan jawaban dengan tombol "Benar" dan "Salah". Apabila jawaban peserta didik benar maka pada kolom jawaban akan muncul "Benar" dengan font berwarna. Dan skor otomatis bertambah menjadi 10 poin. Sedangkan apabila jawaban peserta didik salah, maka pada kolom jawaban akan muncul "Salah" dan skor otomatis akan berkurang sebanyak 10 poin. Di akhir terdapat menu yang berisikan profil dari peneliti sekaligus pembuat media. Terdapat foto dari peneliti, nama dan biodata diri lengkap dari peneliti.

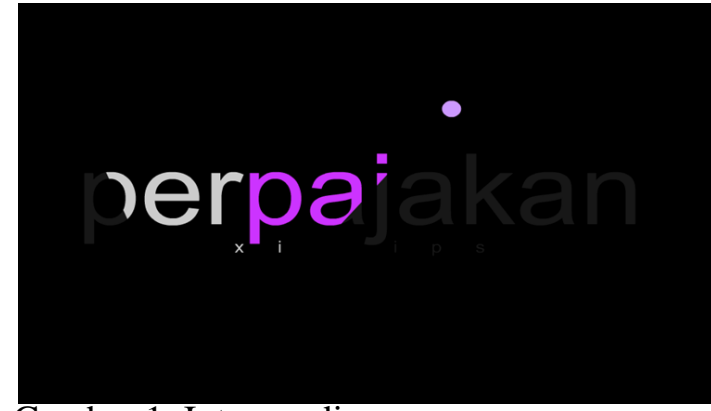

Gambar 1. Intro media

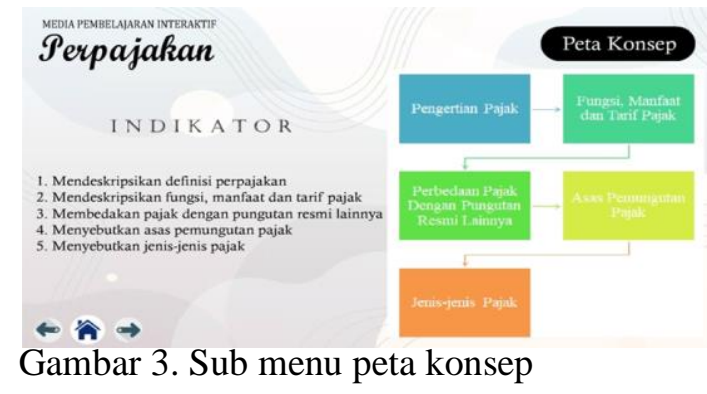

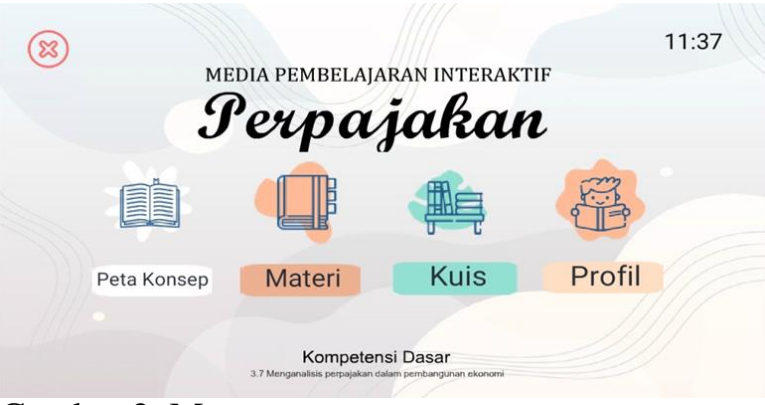

Gambar 2. Menu utama

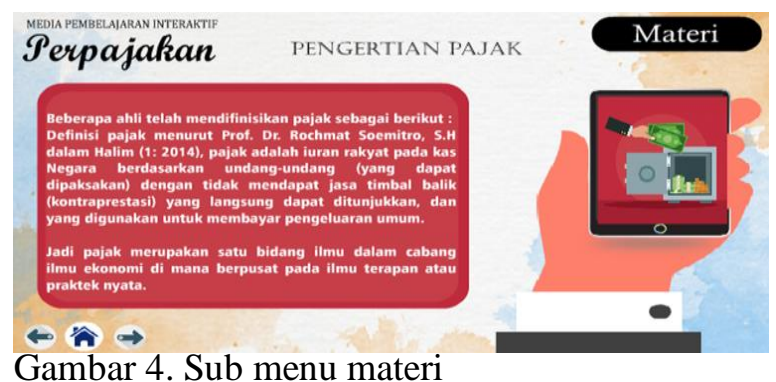

Edukatif : Jurnal Ilmu Pendidikan Vol 3 No 2 Tahun 2021 p-ISSN 2656-8063 e-ISSN 2656-8071 


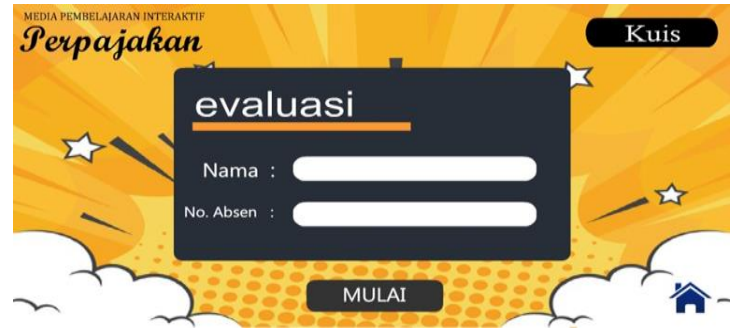

Gambar 5. Sub menu intro kuis

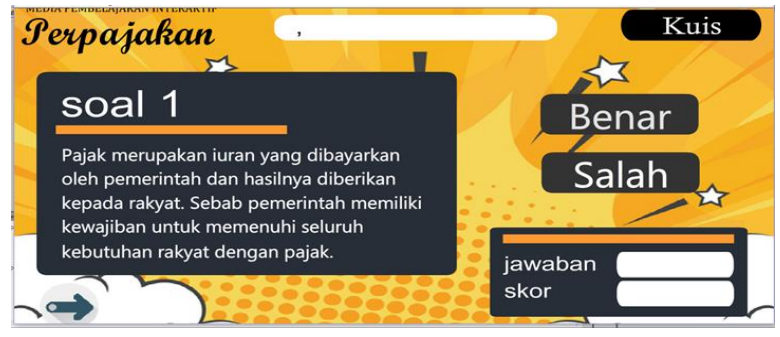

Gambar 6. Sub menu kuis

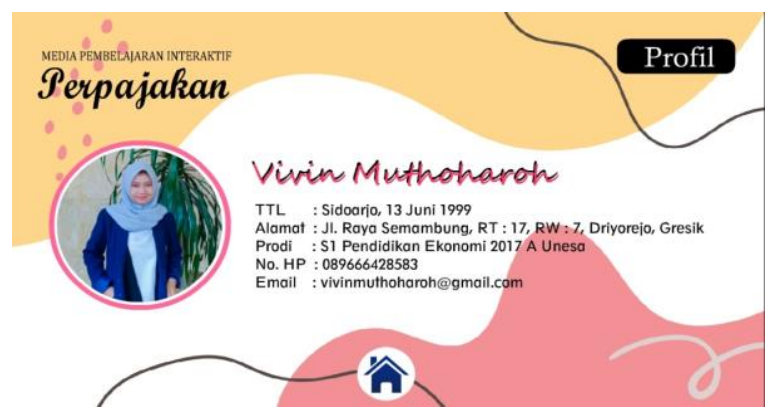

Gambar 7. Sub menu profil

\section{Tahap Pengembangan}

Media pembelajaran sebelum diujicobakan harus melewati prosedur validasi terlebih dahulu oleh dosen ahli materi, ahli media, ahli evaluasi, ahli kepraktisan media dan ahli efektivitas media. Melalui lembar angket yang telah dibagikan untuk dinilai menggunakan skala likert 1 sampai 5.

\section{Kelayakan Media Pembelajaran Perpajakan}

Tabel 2. Rekapitulasi Hasil Uji Kelayakan

\begin{tabular}{|l|l|c|c|}
\hline No. & \multicolumn{1}{|c|}{ Validasi } & Presentase & Kriteria \\
\hline 1. & Validasi dari ahli media & $80 \%$ & Layak \\
\hline 2. & Validasi dari ahli materi & $100 \%$ & Sangat Layak \\
\hline 3. & Validasi dari ahli evaluasi & $77,3 \%$ & Layak \\
\hline \multicolumn{2}{|c|}{ Presentase } & $\mathbf{2 5 7 , 3 \%}$ & - \\
\hline \multicolumn{2}{|c|}{ Rata-Rata Presentase } & $\mathbf{8 5 , 7 \%}$ & Layak \\
\hline
\end{tabular}

Sumber : Data diolah peneliti (2021)

Menurut hasil penelitian yang diperoleh pada validasi media, materi dan evaluasi. Diketahui yakni memperoleh presentase rata-rata sebanyak $85,7 \%$ dengan kriteria layak atau baik. Jadi, media pembelajaran yang dikembangkan sudah memenuhi syarat kelayakan jika ditinjau dari penyajian media, materi dan validasi butir soal untuk digunakan pada proses pembelajaran di kelas.

\section{Kepraktisan Media Pembelajaran Perpajakan}

Tabel 3. Rekapitulasi Hasil Uji Kepraktisan Media

\begin{tabular}{|l|l|c|c|}
\hline No. & \multicolumn{1}{|c|}{ Variabel } & Presentase & Kriteria \\
\hline 1. & Proses Pengembangan & $100 \%$ & Sangat Baik \\
\hline 2. & Kemudahan Penggunaan & $100 \%$ & Sangat Baik \\
\hline
\end{tabular}


371 Media Pembelajaran Interakif Menggunakan Adobe Flash CS6 Untuk Pembelajaran IPS Siswa Sekolah Menengah Atas - Vivin Muthoharoh, Norida Canda Sakti

DOI : https://doi.org/10.31004/edukatif.v3i2.315

\begin{tabular}{|c|c|c|c|}
\hline No. & Variabel & Presentase & Kriteria \\
\hline 3. & Nilai Ekonomis & $100 \%$ & Sangat Baik \\
\hline 4. & Daya Tarik & $100 \%$ & Sangat Baik \\
\hline \multicolumn{2}{|r|}{ Presentase } & $400 \%$ & - \\
\hline & Rata-Rata Presentase & $100 \%$ & Sangat Baik \\
\hline
\end{tabular}

Sumber : data diolah oleh peneliti (2021)

Hasil validasi kepraktisan media oleh ahli kepraktisan media yakni Pak Dr. Norida Canda Sakti, M.Si. dari Jurusan Pendidikan Ekonomi, Universitas Negeri Surabaya. Diketahui mendapatkan hasil yakni sebanyak $100 \%$ dengan kriteria sangat baik. Media pembelajaran diketahui telah memenuhi syarat kepraktisan dan dinilai praktis jika digunakan dalam proses pembelajaran ekonomi di kelas.

\section{Efektivitas Media Pembelajaran Perpajakan}

Tabel 4. Rekapitulasi Hasil Uji Efektivitas Media

\begin{tabular}{|l|l|c|c|}
\hline No. & \multicolumn{1}{|c|}{ Variabel } & Presentase & Kriteria \\
\hline 1. & Minat dan Motivasi & $100 \%$ & Sangat Baik \\
\hline 2. & Fungsi Media & $100 \%$ & Sangat Baik \\
\hline 3. & Reliabilitas & $100 \%$ & Sangat Baik \\
\hline \multicolumn{2}{|c|}{ Presentase } & $\mathbf{3 0 0 \%}$ & - \\
\hline \multicolumn{2}{|c|}{ Rata-Rata Presentase } & $\mathbf{1 0 0 \%}$ & Sangat Baik \\
\hline
\end{tabular}

Sumber : data diolah oleh peneliti (2021)

Pada validasi efektivitas media oleh ahli efektivitas media yakni Pak Dr. Norida Canda Sakti, M.Si. dari Jurusan Pendidikan Ekonomi, Universitas Negeri Surabaya. Didapatkan hasil sebanyak 100\% dengan kriteria sangat baik. Diperoleh hasil bahwa media pembelajaran perpajakan telah memenuhi syarat efektivitas dan dinilai efektif apabila digunakan pada kegiatan belajar di sekolah.

Di bawah ini merupakan contoh tampilan media perpajakan sesudah melalui proses validasi :

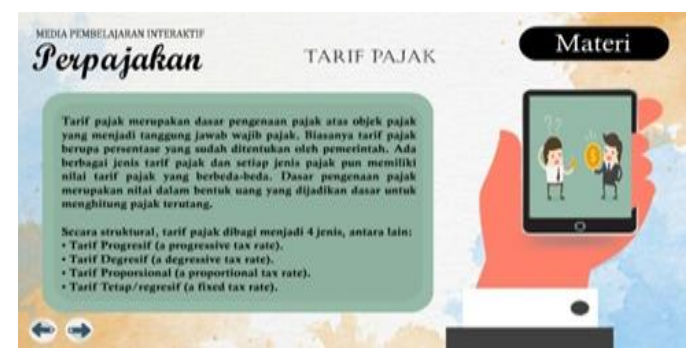

Gambar 8. Tampilan Materi pada media sebelum direvisi

Pada gambar 8 tulisan dinilai validator media terlalu banyak dan font terlalu kecil, sehingga diperlukan revisi untuk menyempurnakan tampilan media pembelajaran. 


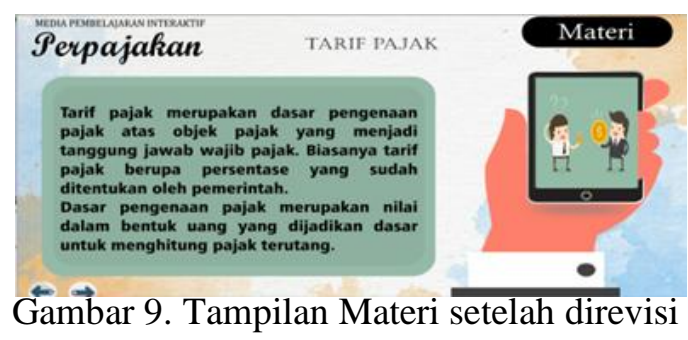

Pada gambar 9 beberapa kata-kata yang tidak penting dihilangkan, dan ukuran font diperbesar sehingga pengguna dalam membaca materi lebih baik.

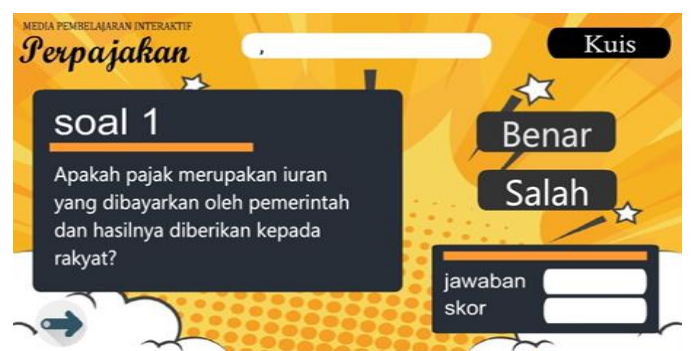

Gambar 10. Tampilan Kuis Sebelum Direvisi

Padagambar 10 soal nomor 1 dinilai validator butir soal tidak relevan dengan jawaban benar dan salah, sehingga soal perlu diganti supaya media pembelajaran perpajakan lebih baik lagi.

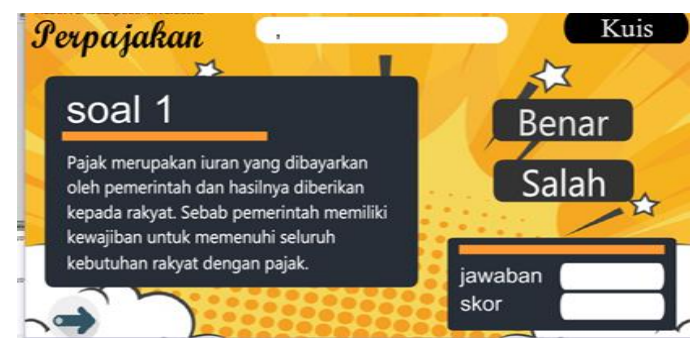

Gambar 11. Tampilan Kuis Setelah Direvisi

Pada gambar 11 soal nomor 1 sudah diganti dan telah dinilai oleh validator dengan benar, sehingga soal sudah layak digunakan .

\section{Kelayakan Media Pembelajaran Ditinjau Dari Respon Peserta Didik}

Media yang sudah divalidasi dan direvisi selanjutnya akan dicobakan secara terbatas kepada 20 siswa Kelas XI IPS SMAN 1 Krian. Peserta didik akan diberikan lembar angket respon responden terhadap media pembelajaran guna mengetahui tingkat kelayakan media jika ditinjau dari respon peserta didik. Berikut tersaji hasil respon peserta didik pada tabel 3 :

Tabel 5. Rekapitulasi Hasil Respon Peserta Didik

\begin{tabular}{|c|l|c|c|}
\hline No. & \multicolumn{1}{|c|}{ Variabel } & Presentase & $\begin{array}{c}\text { Kriteria } \\
\text { Kelayakan }\end{array}$ \\
\hline 1 & Ketertarikan pada Media Pembelajaran & $87 \%$ & Sangat Layak \\
\hline 2 & Minat belajar terhadap Media Pembelajaran & $85 \%$ & Sangat Layak \\
\hline 3 & Kemudahan dalam menggunakan Media Pembelajaran & $95 \%$ & Sangat Layak \\
\hline \multicolumn{2}{r}{ Presentase } & $\mathbf{2 6 7 \%}$ & - \\
\hline
\end{tabular}


373 Media Pembelajaran Interakif Menggunakan Adobe Flash CS6 Untuk Pembelajaran IPS Siswa Sekolah Menengah Atas - Vivin Muthoharoh, Norida Canda Sakti

DOI : https://doi.org/10.31004/edukatif.v3i2.315

\begin{tabular}{|c|c|c|c|}
\hline No. & Variabel & Presentase & $\begin{array}{c}\text { Kriteria } \\
\text { Kelayakan }\end{array}$ \\
\hline \multicolumn{2}{|c|}{ Rata-rata } & $\mathbf{8 9 \%}$ & Sangat Layak \\
\hline
\end{tabular}

Sumber : data diolah oleh peneliti (2021)

Diperoleh nilai rata-rata $89 \%$ dengan kriteria sangat layak. Hal ini menunjukkan respon positif peserta didik terhadap Aplikasi Media Perpajakan yang dikembangkan.

\section{Perbandingan Hasil Belajar Sebelum dan Sesudah Menggunakan Media Pembelajaran}

Untuk menganalisis perbedaan hasil belajar peserta didik sebelum dan sesudah menggunakan media pembelajaran interaktif menggunakan media pembelajaran perpajakan peneliti memberikan Pre-Test dan Post-Test untuk dikerjakan. Menurut uji $\mathrm{N}$-gain yang telah dianalisis diperoleh hasil bahwa sebanyak 17 peserta didik memiliki kriteria nilai tinggi dalam peningkatan hasil belajar sedangkan terdapat 3 peserta didik yang memiliki nilai sedang. Berikut hasil $N$-Gain Score :

Tabel 6. Rekapitulasi Hasil Uji N-Gain Score

\begin{tabular}{|l|c|c|c|}
\hline & Pre-Test & Post-Test & N-Gain Score \\
\hline Jumlah & 1070 & 1840 & 0,83 \\
\hline Rata-rata & 53,5 & 92 & 0,82 \\
\hline
\end{tabular}

Sumber : data diolah oleh peneliti (2021)

Berdasarkan tabel 6. Sebelum menggunakan media peserta didik mendapatkan skor Pre-Test rata-rata 53,5. Kemudian setelah disajikan media pembelajaran peserta didik mengerjakan Post-Test yang telah disajikan dan hasil belajarnya meningkat secara signifikan sebesar 92. Uji N-Gain Score mendapatkan nilai rata-rata sebesar $0,82 \geq 0,3$ maka disimpulkan bahwa terdapat peningkatan hasil belajar secara signifikan setelah dilakukan uji coba terbatas media pembelajaran perpajakan.

Beberapa penelitian terdahulu tentang media pembelajaran menggunakan software sejenis telah dilakukan oleh Umbara dan Nuraeni (2019) bahwa media pembelajaran menggunakan adobe flash cs6 dinilai layak digunakan serta berhasil menambah nilai pada hasil belajar serta minat literasi peserta didik. Selain itu, penelitian yang pernah dilakukan oleh Krismadinata (2019) diperoleh hasil yaitu konten yang terdapat dalam media interaktif terbukti valid, praktis dan efektif dalam meningkatkan hasil belajar dan berguna saat digunakan dalam kegiatan belajar. Hal tersebut menunjukkan bahwa media pembelajaran menggunakan software adobe flash cs6 dinilai mampu menambah dorongan belajar peserta didik dan peningkatan hasil belajar yang signifikan.

Di samping itu terdapat keterbatasan pada penelitian ini yakni media pembelajaran hanya dapat diakses menggunakan Smartphone Android, sehingga pengguna smartphone jenis lain tidak dapat mengakses media pembelajaran. Selain itu materi dalam media yang dikembangkan juga terbatas hanya pada Kompetensi Dasar 3.7 Perpajakan mata pelajaran ekonomi. Dan juga target pengguna pada media terbatas hanya bisa digunakan oleh peserta didk kelas XI IPS SMA.

\section{KESIMPULAN}

Berdasarkan hasil penelitian dengan uji kelayakan pada validator media, validator materi, dan validator evaluasi yang telah dilakukan diperoleh hasil Media Pembelajaran Perpajakan yang dikembangkan dinyatakan layak digunakan dengan presentase kelayakan sebesar $85,7 \%$ (layak). Uji Kepraktisan media 
374 Media Pembelajaran Interakif Menggunakan Adobe Flash CS6 Untuk Pembelajaran IPS Siswa Sekolah Menengah Atas - Vivin Muthoharoh, Norida Canda Sakti

DOI : https://doi.org/10.31004/edukatif.v3i2.315

menurut hasil penelitian diketahui mendapatkan nilai presentase rata-rata $100 \%$ dengan kriteria sangat praktis digunakan. Jadi, disimpulkan bahwa Media Pembelajaran Perpajakan yang dikembangkan telah memenuhi syarat kepraktisan untuk digunakan dalam proses pembelajaran di Kelas XI IPS dengan kriteria kelayakan $\geq$ $61 \%$. Analisis validasi ahli efektivitas media didapatkan jumlah presentase rata-rata $100 \%$ dengan kategori sangat efektif. Jadi, disimpulkan bahwa Media Pembelajaran Perpajakan yang dikembangkan telah memenuhi syarat efektivitas untuk digunakan dalam proses pembelajaran di Kelas XI IPS dengan kriteria kelayakan $\geq$ $61 \%$.

Hasil uji coba terbatas yang menunjukkan respon peserta didik terhadap media pembelajaran perpajakan menyatakan bahwa Media Pembelajaran Perpajakan yang dikembangkan mendapat respon positif dari peserta didik. Dengan nilai rata-rata presentase sebesar $89 \%$ dengan kriteria kelayakan sangat layak $\geq$ 81\%. Hasil uji coba terbatas juga menunjukkan bahwa hasil belajar peserta didik sebelum dan sesudah menggunakan Media Pembelajaran Perpajakan memperoleh nilai rata-rata setelah melakukan Post-Test sebanyak 92 atau memperoleh nilai lebih baik sebanyak 38,5 dibandingkan dengan nilai rata-rata Pre-Test atau sebelum diberikan media pembelajaran dengan nilai sebanyak 53,5. Bahwa terdapat perbedaan yang signifikan pada hasil belajar peserta didik pada saat sebelum dan sesudah menggunakan media pembelajaran perpajakan. Penelitian pengembangan media pembelajaran interaktif .

Media pembelajaran yang sudah dikembangkan oleh peneliti divalidasi dan mendapatkan kriteria layak, efektif dan praktis digunakan dalam peningkatan hasil belajar siswa di mana dalam media terdapat konten yang interaktif serta berbagai macam fitur yang mudah diakses oleh guru dan peserta didik di sekolah. Media juga berperan memberikan respon positif dan rasa antusias pada saat digunakan di mana penggunaan media pembelajaran yang sangat fleksibel yang mampu dipakai dalam proses penunjang pembelajaran di manapun dan kapanpun.

\section{DAFTAR PUSTAKA}

Asrori, M. (2016). Pengertian, Tujuan Dan Ruang Lingkup Strategi Pembelajaran. MADRASAH. https://doi.org/10.18860/jt.v6i2.3301

Bustomi, A. Y. (2010). Aplikasi Pembelajaran Panca Indra Pada Manusia Berbasis Android. Telematika, Vol. 3, No. http://ejournal.amikompurwokerto.ac.id/index.php/telematika/article/view/195

Fauziah, I., Sutrisno, \& Suwarni. (2016). Pengembangan E-Modul Berbasis Adobe Flash CS6 pada Mata Pelajaran Penataan Barang Dagang. Jurnal Pendidikan Bisnis Dan Manajemen, Vol. 2, No. http://journal2.um.ac.id/index.php/jpbm/article/view/1703

Krismadinata, K., Elfizon, E., \& Santika, T. (2019). Developing Interactive Learning Multimedia on Basic Electrical Measurement Course. 299(Ictvet 2018), 305-308. https://doi.org/10.2991/ictvet-18.2019.69

Kurniawati, I. D., \& Nita, S.-. (2018). MEDIA PEMBELAJARAN BERBASIS MULTIMEDIA INTERAKTIF UNTUK MENINGKATKAN PEMAHAMAN KONSEP MAHASISWA. DOUBLECLICK: Journal of Computer and Information Technology. https://doi.org/10.25273/doubleclick.v1i2.1540

Mankiw, N. G. (2013). A Lecture Presentation in PowerPoint to Accompany Principles of Economics Ten Principles of Economics.

Muhson, A. (2010). PENGEMBANGAN MEDIA PEMBELAJARAN BERBASIS TEKNOLOGI INFORMASI. Jurnal Pendidikan Akuntansi Indonesia. https://doi.org/10.21831/jpai.v8i2.949

Mustarin, A., Arifyansah, R., \& Rais, M. (2019). PENERAPAN MEDIA PEMBELAJARAN ADOBE FLASH CS6 DALAM MENINGKATKAN HASIL BELAJAR SISWA KELAS X ATPH PADA MATA PELAJARAN ALAT DAN MESIN PERTANIAN DI SMKN 4 JENEPONTO. Jurnal 
375 Media Pembelajaran Interakif Menggunakan Adobe Flash CS6 Untuk Pembelajaran IPS Siswa Sekolah Menengah Atas - Vivin Muthoharoh, Norida Canda Sakti

DOI : https://doi.org/10.31004/edukatif.v3i2.315

Pendidikan Teknologi Pertanian. https://doi.org/10.26858/jptp.v5i1.8189

Osman, A., Yahaya, W. A. J. W., \& Ahmad, A. C. (2015). Educational Multimedia App for Dyslexia Literacy Intervention: A Preliminary Evaluation. Procedia - Social and Behavioral Sciences. https://doi.org/10.1016/j.sbspro.2015.01.489

Priandana, V., \& Asto. (2015). Pengembangan Media Pembelajaran Multimedia Interaktif Berbantuan Software Macromedia Flash Pada Kompetensi Dasar Menerapkan Macam-Macam Gerbang Dasar Rangkaian Logika Di SMK Negeri 2 Bojonegoro. Jurnal Pendidikan Teknik Jurnal Pendidikan Teknik Sipil, 33.

Sefriani, R., \& Sepriana, R. (2020). Pengembangan Media E-Learning Berbasis Schoology pada Pembelajaran Kurikulum Pendidikan Teknologi dan Kejuruan. Edukatif: Jurnal Ilmu Pendidikan, 2(1), 8-14.

Sugiyono. (2013). Metode Penelitian Pendidikan Pendekatan Kuantitatif, Kualitatif, dan R\&D (Cetakan ke). Afabeta.

Sugiyono. (2016). Metode Penelitian dan Pengembangan (Research and Development/R\&D). Bandung: Alfabeta. https://doi.org/10.1016/j.drudis.2010.11.005

Syupriyanti, L., Firman, \& Neviyarni. (2019). PENGARUH MEDIA AUDIO VISUAL INTERAKTIF MENGGUNAKAN PENDEKATAN CTL DALAM PEMBELAJARAN TEMATIK TERPADU TERHADAP HASIL BELAJAR DAN MOTIVASI SISWA DI SEKOLAH DASAR. Edukatif: Jurnal Ilmu Pendidikan, 1 No. 3. https://edukatif.org/index.php/edukatif/index

Tafonao, T. (2018). PERANAN MEDIA PEMBELAJARAN DALAM MENINGKATKAN MINAT BELAJAR MAHASISWA. Jurnal Komunikasi Pendidikan. https://doi.org/10.32585/jkp.v2i2.113

Thiagarajan, S. (1974). Instructional Development For Training Teachers of Exceptional Childern : A Source Book. University of Minnesota.

Umbara, U., \& Nuraeni, Z. (2019). Implementation of Realistic Mathematics Education Based on Adobe Flash Professional CS6 To Improve Mathematical Literacy. Infinity Journal, Vol. 8, No. http://ejournal.stkipsiliwangi.ac.id/index.php/infinity/article/view/1037 